\title{
Klasifikasi Penggunaan Lahan
}

\author{
Nurfatimah, M.Si
}

Dosen Universitas Islam Negeri Alauddin Makassar nurfatimah.nurfatimah91@gmail.com

Penggunaan lahan di suatu wilayah, baik di perkotaan maupun di perdesaan sangatlah kompleks. Oleh karena itu, untuk keperluan inventarisasi di antaranya, diperlukan adanya klasifikasi atau pengelompokkan. Menurut Abbler (1972), klasifikasi merupakan suatu proses pengelompokan data yang bersifat induktif sebagai generalisasi secara sistematik dari suatu objek atau fenomena (Sitawati, 2002). Pengelompokan siasanya dilakukan atas dasar kesamaan sifat dan atas dasar kriteria - kriteria atribut tertentu, misalnya kriteria jenis penggunaan lahan banyak dilakukan oleh beberapa peneliti. Berikut ini, beberapa ulasan terhadap klasifikasi penggunaan lahan.

\section{A. Klasifikasi Penggunaan Lahan Menurut Standar Nasional Indonesia (SNI)}

Standar Nasional Indonesia menggunakan terminology penutup lahan dalam mengelompokkan penggunaan lahan, membedakan klas penggunaan lahan berdasarkan skala 1:1.000.000, 1:250.000 dan 1:50.000/25.000. Tabel 1 dan 2 di bawah ini mempresentasikan klasifikasi penutup lahan skala yang dimaksudkan di atas.

Tabel 1.1 Klasifikasi Penutup Lahan Skala 1:1.000.000

\begin{tabular}{|c|c|}
\hline No & Klas Penutup Lahan \\
\hline \multirow[t]{11}{*}{1.} & Daerah Vegetasi \\
\hline & 1.1 Daerah Pertanian \\
\hline & 1.1.1 Sawah \\
\hline & 1.1.2 Ladang, tegal atau huma \\
\hline & 1.1.3 Perkebunan \\
\hline & 1.2 Daerah Bukan Pertanian \\
\hline & 1.2.1 Hutan lahan kering \\
\hline & 1.2.2 Hutan lahan basah \\
\hline & 1.2.3 Semak dan belukar \\
\hline & 1.2.4 Padang rumput alang - alang dan sabana \\
\hline & 1.2.5 Rumput rawa \\
\hline \multirow[t]{12}{*}{2.} & Daerah Tak Bervegetasi \\
\hline & 2.1 Lahan Terbuka \\
\hline & 2.2 Pemukiman dan lahan bukan pertanian \\
\hline & 2.2.1 Lahan terbangun \\
\hline & 2.2.1.1 Permukiman \\
\hline & 2.2.1.2 Jaringan Jalan (Jalan Arteri dan Jalan Kolektor) \\
\hline & 2.2.1.3 Jaringan jalan kereta api \\
\hline & 2.2.1.4 Bandar udara domestic / internasional \\
\hline & 2.2.1.5 Pelabuhan Laut \\
\hline & 2.2.2 Lahan tidak terbangun \\
\hline & 2.3 Perairan \\
\hline & 2.3.1 Danau atau waduk \\
\hline
\end{tabular}




\subsubsection{Rawa \\ 2.3.3 Sungai \\ 2.3.4 Terumbu Karang}

Sumber: Badan Standarisasi Nasional, 2010

Tabel 1.2 Klasifikasi Penutup Lahan Skala 1:250.000

\begin{tabular}{|c|c|}
\hline No & Klas Penutup Lahan \\
\hline \multirow[t]{14}{*}{1.} & Daerah Vegetasi \\
\hline & 1.1 Daerah Pertanian \\
\hline & 1.1.1 Sawah \\
\hline & 1.1.2 Sawah pasang surut \\
\hline & 1.1.3 Ladang \\
\hline & 1.1.4 Perkebunan \\
\hline & 1.1.5 Perkebunan Campuran \\
\hline & 1.1.6 Tanaman Campuran \\
\hline & 1.2 Daerah Bukan Pertanian \\
\hline & 1.2.1 Hutan lahan kering \\
\hline & 1.2.2 Hutan lahan basah \\
\hline & 1.2.3 Semak dan belukar \\
\hline & 1.2.4 Padang rumput alang - alang dan sabana \\
\hline & 1.2.5 Rumput rawa \\
\hline \multirow[t]{23}{*}{2.} & Daerah Tak Bervegetasi \\
\hline & 2.1 Lahan Terbuka \\
\hline & 2.1.1 Lahar dan Lava \\
\hline & 2.1.2 Hamparan pasir pantai \\
\hline & 2.1.3 Beting pantai \\
\hline & 2.1.4 Gumuk pasir \\
\hline & 2.2 Pemukiman dan lahan bukan pertanian \\
\hline & 2.2.1 Lahan terbangun \\
\hline & 2.2.1.1 Permukiman \\
\hline & 2.2.1.2 Jaringan Jalan (Jalan Arteri, Jalan Kolektor dan Jalan Lokal) \\
\hline & 2.2.1.3 Jaringan jalan kereta api \\
\hline & 2.2.1.4 Bandar udara domestic / internasional \\
\hline & 2.2.1.5 Pelabuhan Laut \\
\hline & 2.2.2 Lahan tidak terbangun \\
\hline & 2.2.2.1 Pertambangan \\
\hline & 2.2.2.2 Tempat penimbunan sampah \\
\hline & 2.3 Perairan \\
\hline & 2.3.1 Danau atau waduk \\
\hline & 2.3.2 Tambak \\
\hline & 2.3.3 Rawa \\
\hline & 2.3.4 Sungai \\
\hline & 2.3.5 Terumbu Karang \\
\hline & 2.3.6 Gosong pantai \\
\hline
\end{tabular}

Sumber: Badan Standarisasi Nasional, 2010 


\section{B. Klasifikasi Penggunaan Lahan Menurut National Landuse Database}

Sistem klasifikasi penggunaan lahan National Landuse Database merupakan system penggunaan lahan yang dirintis oleh Pemerintah Inggris. Sistem klasifikasi ini mengelompokkan penggunaan lahan atas 12 divisi utama dan 49 kelas. Table 3 di bawah ini memrepresentasikan system klasifikasi penggunaan lahan National Landuse Database.

Tabel 1.3 Klasifikasi Penggunaan Lahan National Landuse Database

\begin{tabular}{|c|c|}
\hline Divisi & Kelas \\
\hline \multirow[t]{6}{*}{ 1. Pertanian } & 1. Sawah/tanaman pangan \\
\hline & 2. Lading \\
\hline & 3. Tanah hijau \\
\hline & 4. Kebun Hortikultura \\
\hline & 5. Padang rumput \\
\hline & 6. Batas lading \\
\hline \multirow[t]{7}{*}{ 2. Daerah hutan } & 1. Hutan \\
\hline & 2. Hutan campuran \\
\hline & 3. Hutan berdaun lebar \\
\hline & 4. Hutan kecil \\
\hline & 5. Semak belukar \\
\hline & 6. Hutan gundul \\
\hline & 7. Lahan penghijauan \\
\hline \multirow[t]{4}{*}{ 3. Padang rumput } & 1. Padang rumput \\
\hline & 2. Semak \\
\hline & 3. Pakis \\
\hline & 4. Dataran tinggi \\
\hline \multirow[t]{6}{*}{ 4. Air dan lahan basah } & 1. Laut/muara \\
\hline & 2. Air terjun \\
\hline & 3. Sungai \\
\hline & 4. Rawa air tawar \\
\hline & 5. Rawa air garam \\
\hline & 6. Rawa \\
\hline \multirow[t]{4}{*}{ 5. Batuan dan tanah pesisir } & 1. Batuan dasar \\
\hline & 2. Batuan pantai dan tebing \\
\hline & 3. Pasang surut pasir dan lumpur \\
\hline & 4. Bukit pasir \\
\hline \multirow{2}{*}{$\begin{array}{l}\text { 6. Barang Tambang dan tempat } \\
\text { pembuangan akhir }\end{array}$} & 1. Tambang \\
\hline & 2. TPA \\
\hline \multirow[t]{2}{*}{ 7. Rekreasi } & 1. Rekreasi di dalam ruangan \\
\hline & 2. Rekreasi di luar ruangan \\
\hline \multirow[t]{5}{*}{ 8. Transportasi } & 1. Jalan \\
\hline & 2. Parkir mobil \\
\hline & 3. Jalan kereta api \\
\hline & 4. Bandara \\
\hline & 5. Pelabuhan \\
\hline 9. Pemukiman & 1. Permukiman \\
\hline
\end{tabular}




\begin{tabular}{|c|c|}
\hline & 2. Lembaga kemasyarakatan \\
\hline \multirow[t]{3}{*}{ 10. Bangunan umum } & 1. Bangunan institusi \\
\hline & 2. Bangunan Pendidikan \\
\hline & 3. Bangunan keagamaan \\
\hline \multirow[t]{5}{*}{ 11. Industry dan komersial } & 1. Industry \\
\hline & 2. Kantor \\
\hline & 3. Gudang \\
\hline & 4. Sarana/fasilitas \\
\hline & 5. Bangunan pertanian \\
\hline \multirow[t]{3}{*}{ 12. Lahan / Bangunan Kosong } & $\begin{array}{l}\text { 1. Sebelu dikembangkan } \\
\text { kemudian kosong }\end{array}$ \\
\hline & 2. Bangunan kosong \\
\hline & 3. Bangunan terlantar \\
\hline
\end{tabular}

Sumber: National Landuse Database, 2006

C. Klasifikasi Penggunaan Lahan Menurut Peraturan Menteri Negara Agraria / Kepaa Badan Pertanahan Nasional Nomor 1 Tahun 1997 Tentang Pemetaan Penggunaan Tanah Perdesaan, Penggunaan Tanah Perkotaan, Kemampuan Tanah dan Penggunaan Simbol/Warna Untuk Penyajian dan Peta

Badan Pertanahan Nasional membagi pengelompokan penggunaan lahan berdasarkan lokasinya di pedesaan dan di perkotaan. Berikut ini, jenis - jenis penggunaan tanah perdesaan menurut Badan Pertanahan Nasional

Jenis - jenis penggunaan tanah perdesaan yaitu sebagai berikut:

1. Tanah perkampungan adalah areal tanah yang digunakan untuk kelompok bangunan pada ataupun jarang sebagai tempat tinggal penduduk untuk dimukimi secara menetap

2. Tanah industri adalah tanah areal yang digunakan untuk kegiatan ekonomi berupa proses pengolahan bahan - bahan baku menjadi barang jadi/setengah jadi dan atau setengah jadi menjadi barang jadi.

3. Tanah pertambangan adalah areal tanah yang dieksploitasi bagi pengambilan bahan - bahan galian yang dilakukan secara terbuka dan atau tertutup.

4. Tanah persawahan adalah areal tanah pertanian basah dan/atau kering yang digenangi air secara periodic dan/atau terus menerus ditanami padi dan/atau diselingi tanaman tebu, tembakau, dan/atau tanaman semusim lainnya.

5. Pertanian tanah kering semusim adalah areal pertanian yang tidak pernah diairi dan mayorotas ditanami dengan tanaman umur pendek.

6. Tanah kebun adalah areal yang ditanami rupa - rupa jenis tanaman keras dan/atau tanaman semusim dan atau kombinasi tanaman keras dan semusim atau tanaman buah - buahan serta tidak jelas mana yang menonjol.

7. Tanah perkebunan adalah areal tanah yang ditanami tanaman keras dengan satu jenis tanaman.

8. Padang adalah areal terbuka karena hanya ditumbuhi tanaman rendah dari keluarga rumput dan semak rendah.

9. Hutan adalah areal yang ditumbuhi oelh pepohonan yang tajuk pohonnya dapat saling menutupi/bergesekan. 
10. Perairan darat, adalah areal tanah yang digenangi air, secara permanen baik buatan maupun alami.

11. Tanah terbuka adalah areal yang tidak digarap karena tidak subur dan/atau menjadi tidak subur setelah digarap serta tidak ditumbuhi tanaman.

12. Lain - lain adalah area; tanah yang digunakan bagi prasarana seperti: jalan, sungai, dan saluran yang merupakan buatan manusia maupun alamiah.

Jenis - jenis penggunaan tanah perkotaan yaitu sebagai berikut:

1. Tanah perumahan adalah bidang - bidang tanah yang digunakan untuk kelompok rumah yang berfungsi sebagai lingkungan tempat tinggal atau ligkungan hunian yang dilengkapi dengan prasarana dan sarana lingkungan.

2. Tanah perusahaan adalah bidang - bidang tanah yang digunakan untuk suatu badan hukum dan/atau badan usaha milik pemerintah maupun swasta untuk kegiatan ekonomi yang bersifat komersial bagi pelayanan perekonomian dan.atau tempat transaksi barang dan jasa.

3. Tanah industry adalah bidang - bidang tanah yang digunakan untuk suatu bahan hukum dan atau badan usaha milik pemerintah maupun swasta untuk kegiatan ekonomi yang bersifat komersil bagi pelayanan perekonomian dan/atau tempat transaksi barang dan jasa.

4. Tanah jasa adalah bidang - bidang tanah yang digunakan untuk suatu kegiatan pelayanan social dan budaya bagi masyarakat kota yang dilaksanakan oleh badan dan/atau organisasi kemasyarakatan pemerintah maupun swasta yang menitikberatkan kegiatan bertujuan untuk pelayanan nonkomersial.

5. Tanah tidak ada bangunan adalah bidang - bidang tanah di dalam wilayah perkotaan yang belum atau tidak digunakan untuk pembangunan perkotaan.

6. Tanah terbuka adalah bidang - bidang tanah yang tidak dibangun dan berfungsi sebagai ruang terbuka atau tanaman.

7. Tanah Non-Urban adalah areal tanah/ bidang - bidang tanah di dalam wilayah perkotaan yang dimanfaatkan untuk kegiatan pertanian dalam arti luas.

\section{Klasifikasi Penggunaan Lahan pada Perencanaan Tata Ruang}

Dalam kaitannya dengan penataan ruang, berdasarkan fungsi utamanya, wilayah yang ada di permukaan bumi terbagi menjadi dua, yaitu sebagai berikut:

1. Kawasan Lindung, adalah wilayah yang ditetapkan dengan fungsi utama melindungi kelestarian lingkungan hidup yang mencakup sumber daya alam dan sumber daya buatan (UU Penataan Ruang NO.26/2007).

2. Kawasan Budidaya, adalah wilayah yang ditetapkan dengan fungsi utama untuk dibudidayakan atas dasar kondisi dan potensi sumber daya alam, sumber daya manusia dan sumber daya buatan (UU Penataan Ruang No. 26/2007). 
Tabel 1.4 Klasifikasi Kawasan Lindung

\begin{tabular}{|c|c|}
\hline Jenis & Definisi \\
\hline \multicolumn{2}{|c|}{ A. Kawasan Yang memberikan perlindungan bagi Kawasan bawahnya } \\
\hline $\begin{array}{l}\text { 1. Kawasan hutan berfungsi } \\
\text { lindung }\end{array}$ & $\begin{array}{l}\text { Kawasan hutan yang memiliki sifat khas yang } \\
\text { mempunyai fungsi pokok pengawetan } \\
\text { keanekaragaman tumbuhan dan satwa serta } \\
\text { ekosistemnya, dan atau yang mampu memberikan } \\
\text { perlindungan kepada Kawasan sekitar maupun } \\
\text { bawahnya yaitu sebagai pengatur tata air, pencegah } \\
\text { banjir, dan erosi, serta memelihara kesuburan tanah. }\end{array}$ \\
\hline 2. Kawasan bergambut & $\begin{array}{l}\text { Kawasan yang unsur pembentuk tanahnya Sebagian } \\
\text { besar berupa sisa - sisa bahan organic yang tertimbun } \\
\text { dalam waktu lama. }\end{array}$ \\
\hline 3. Kawasan resapan air & $\begin{array}{l}\text { Kawasan yang mempunyai kemampuan tinggi untuk } \\
\text { meresapkan air hujan sehingga merupakan tempat } \\
\text { pengisian air hujan sehingga merupakan tempat } \\
\text { pengisian air bumi yang berguna sebagai sumber air. }\end{array}$ \\
\hline \multicolumn{2}{|l|}{ B. Kawasan Suaka Alam } \\
\hline $\begin{array}{l}\text { 1. Kawasan cagar alam/ cagar } \\
\text { bahari }\end{array}$ & $\begin{array}{l}\text { Kawasan suaka alam yang karena keadaan alamnya } \\
\text { mempunyai kekhasan tumbuhan satwa dan } \\
\text { ekosistemnya atau ekosistem tertentu yang perlu } \\
\text { dilindungi dan perkembangannya berlangsung secara } \\
\text { alami. }\end{array}$ \\
\hline $\begin{array}{l}\text { 2. Kawasan suaka margasatwa / } \\
\text { suaka perikanan }\end{array}$ & $\begin{array}{l}\text { Kawasan suaka alam yang ditunjuk merupakan tempat } \\
\text { hidup dan perkembangbiakan dari suatu jenis satwa } \\
\text { yang perlu dilakukan upaya jenis satwa yang perlu } \\
\text { dilakukan upaya konservasinya, memiliki } \\
\text { keanekaragaman dan populasi satwa yang tinggi, } \\
\text { da/atau merupakan tempat dan kehidupan jenis satwa } \\
\text { migran tertentu. }\end{array}$ \\
\hline $\begin{array}{l}\text { 3. Kawasan suaka alam laut dan } \\
\text { perairan lainnya }\end{array}$ & $\begin{array}{l}\text { Kawasan yang memiliki ekosystem khas di lautan } \\
\text { maupun perairan lainnya, yang merupakan habitat } \\
\text { alami yang memberikan tempat maupun perlindungan } \\
\text { bagi perkembangan keanekaragaman tumbuhan dan } \\
\text { satwa yang ada. }\end{array}$ \\
\hline \multicolumn{2}{|l|}{ C. Kawasan Pelestarian } \\
\hline $\begin{array}{l}\text { 1. Taman Nasional/Taman Laut } \\
\text { Nasional }\end{array}$ & $\begin{array}{l}\text { Kawasan pelestarian alam yang dikelola dengan } \\
\text { system zonasi yang dimanfatkan untuk tujuan } \\
\text { pengembangan ilmu pengetahuan, Pendidikan, } \\
\text { pariwisata dan rekreasi. }\end{array}$ \\
\hline 2. Taman hutan raya & $\begin{array}{l}\text { Kawasan pelestarian yang terutama dimanfaatkan } \\
\text { untuk tujuan koleksi tumbuhan dan/atau satwa, alami } \\
\text { atau buatan, jenis asli dan/atau bukan asli, } \\
\text { pengembangan ilmu pengetahuan, pendidikan, dan } \\
\text { Latihan, budaya pariwisata dan rekreasi. }\end{array}$ \\
\hline
\end{tabular}




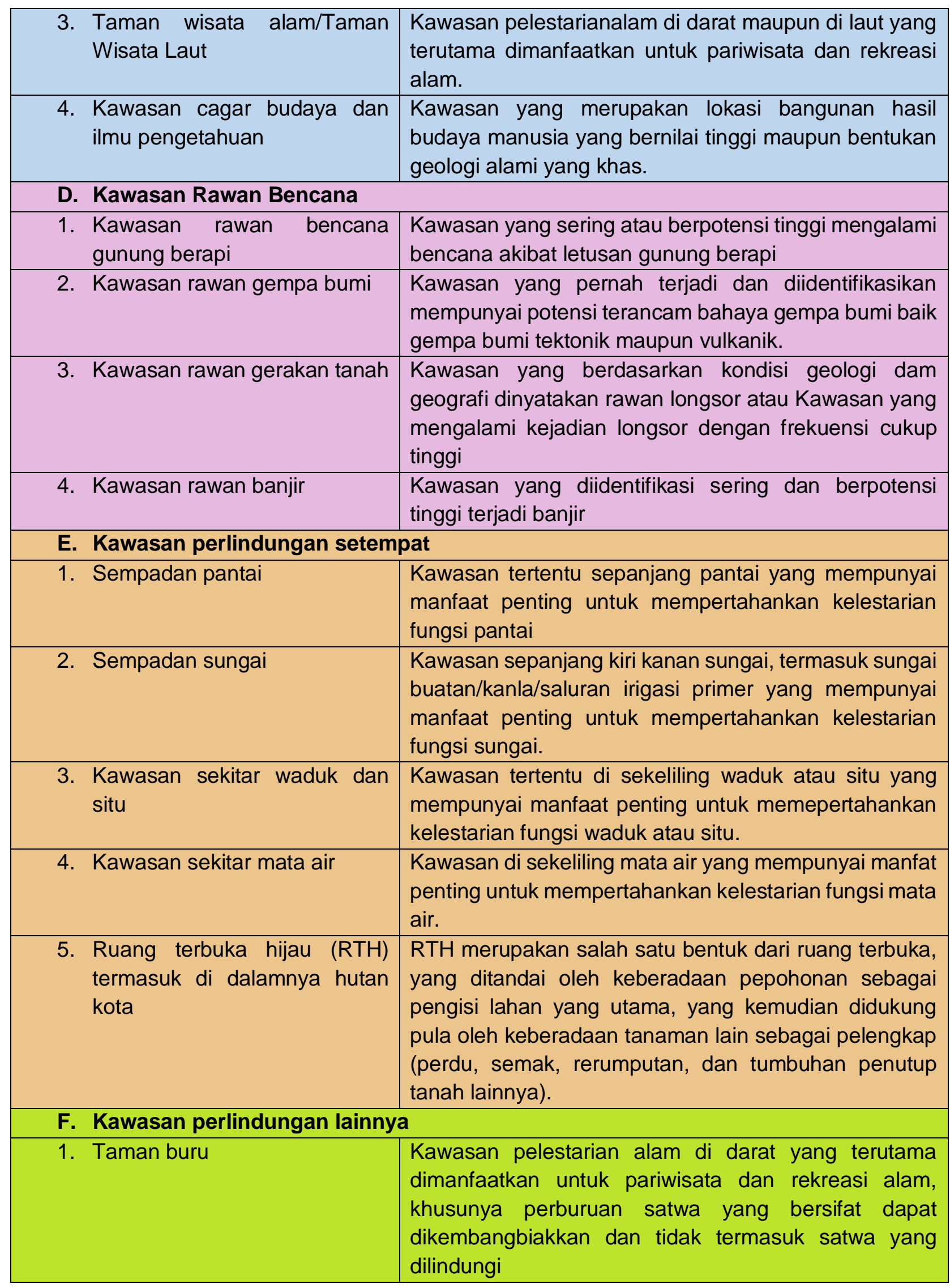




\begin{tabular}{|l|l|}
\hline $\begin{array}{l}\text { 2. Daerah perlindungan laut local } \\
\text { (DPL) }\end{array}$ & $\begin{array}{l}\text { Wilayah perairan laut di suatu desa/kecamatan yang } \\
\text { disepakati Bersama oleh warga setempat untuk } \\
\text { ditetapkan sebagai DPL }\end{array}$ \\
\hline $\begin{array}{l}\text { 3. Kawasan perlindungan plasma } \\
\text { nuftah eks-situ }\end{array}$ & $\begin{array}{l}\text { Kawasan di luar Kawasan suaka alam dan pelestarian } \\
\text { alam yang diperuntukkan bagi pengembangan dan } \\
\text { pelestarian pemanfaatan plasma nuftah tertentu. }\end{array}$ \\
\hline 4. Kawasan pengungsian satwa & $\begin{array}{l}\text { Kawasan yang memiliki fungsi sebagai tempat } \\
\text { perlindungan satwa5 }\end{array}$ \\
\hline $\begin{array}{l}\text { Kawasan pantai berhutan } \\
\text { bakau }\end{array}$ & $\begin{array}{l}\text { Kawasan pesisir laut yang merupakan habitat alami } \\
\text { hutan bakau yang berfungsi memberi perlindungan } \\
\text { kepda perikehidupan pantai dan lautan. }\end{array}$ \\
\hline
\end{tabular}

Sumber: Direktorat Jenderal Penataan Ruang Kemeterian Pekerjaan Umum, Pedoman Kriteria Teknis Kawasan Lindung, 2007

Tabel 1.5 Klasifikasi Kawasan Budidaya

\begin{tabular}{|c|c|}
\hline Jenis & Definisi \\
\hline \multicolumn{2}{|l|}{ A. Kawasan Hutan Produksi } \\
\hline $\begin{array}{l}\text { 1. Kawasan hutan produksi } \\
\text { terbatas }\end{array}$ & $\begin{array}{l}\text { Kawasan yang diperuntukkan bagi hutan produksi } \\
\text { terbatas di mana eksploitasinya hanya dapat dengan } \\
\text { tebang pilih tanam }\end{array}$ \\
\hline $\begin{array}{l}\text { 2. Kawasan hutan produksi } \\
\text { tetap }\end{array}$ & $\begin{array}{l}\text { Kawasan yang diperuntukkan bagi hutan produksi tetap } \\
\text { dimana eksploitasinya dapat dengan tebang pilih atau } \\
\text { tebang habis dan tanam }\end{array}$ \\
\hline $\begin{array}{l}\text { 3. Kawasan hutan produksi } \\
\text { konversi }\end{array}$ & $\begin{array}{l}\text { Kawasan hutan yang bilaman diperlukan dapat } \\
\text { dialihgunakan }\end{array}$ \\
\hline 4. Kawasan hutan rakyat & $\begin{array}{l}\text { Kawasan hutan yang dapat dibudidayakan oleh } \\
\text { masyarakat sekitarnya dengan mengikuti ketentuan } \\
\text { yang ditetapkan }\end{array}$ \\
\hline \multicolumn{2}{|l|}{ B. Kawasan pertanian } \\
\hline $\begin{array}{l}\text { 1. Kawasan tanaman pangan } \\
\text { Lahan basah }\end{array}$ & $\begin{array}{l}\text { Kawasan yang diperuntukkan bagi tanaman pangan } \\
\text { lahan basah dimana pengairannya dapat diperoleh } \\
\text { secara alamiah ataupun teknis }\end{array}$ \\
\hline $\begin{array}{l}\text { 2. Kawasan tanaman pangan } \\
\text { lahan kering }\end{array}$ & $\begin{array}{l}\text { Kawasan yang diperuntukkan bagi tanaman pangan } \\
\text { lahan kering untuk tanaman pangan lahan kering untuk } \\
\text { tanaman palawija, holtikultura, atau tanaman pangan }\end{array}$ \\
\hline $\begin{array}{l}\text { 3. Kawasan tanaman tahunan } \\
\text { / perkebunan }\end{array}$ & $\begin{array}{l}\text { Kawasan yang diperuntukkan bagi tanaman tahunan / } \\
\text { perkebunan yang menghasikan baik bahan pangan dan } \\
\text { bahan baku industry. }\end{array}$ \\
\hline 4. Kawasan peternakan & $\begin{array}{l}\text { Kawasan yang secara teknis dapat digunakan untuk } \\
\text { usaha peternakan baik sebagai sambilan, cabang } \\
\text { usaha, usaha pokok maupun industry, serta sebagai } \\
\text { padang penggembalaan ternak. }\end{array}$ \\
\hline 5. Kawasan perikanan darat & $\begin{array}{l}\text { Kawasan yang diperuntukkan bagi perikanan, baik } \\
\text { berupa pertambakan/kolam maupun perairan darat } \\
\text { lainnya. }\end{array}$ \\
\hline
\end{tabular}




\begin{tabular}{|c|l|}
\hline $\begin{array}{c}\text { 6. Kawasan perikanan ikan } \\
\text { payau dan laut }\end{array}$ & $\begin{array}{l}\text { Kawasan yang diperuntukkan untuk kegiatan perikanan } \\
\text { air payau dan laut dalam bentuk budidaya maupun } \\
\text { penagkapan. }\end{array}$ \\
\hline C. Kawasan Pertambangan \\
\hline 1. Kawasan pertambangan & $\begin{array}{l}\text { Kawasan yang diperuntukkan bagi pertambangan baik } \\
\text { wilayah yang sedang maupun yang akan segera } \\
\text { dilakukan kegiatan pertambangan. }\end{array}$ \\
\hline D. Kawasan budidaya lainnya & $\begin{array}{l}\text { Kawasan yang diperuntukkan bagi industry, berupa } \\
\text { tempat pemusatan kegiatan industri }\end{array}$ \\
\hline 1. Kawasan perindustrian & Kawasan yang diperuntukkan bagi kegiatan pariwisata \\
\hline 2. Kawasan pariwisata & $\begin{array}{l}\text { Kawasan yang secara teknis dapat digunakan untuk } \\
\text { permukiman yang aman dari bahaya bencana alam } \\
\text { maupun buatan manusia, sehat dan mempunyai akses } \\
\text { untuk kesempatan berusaha }\end{array}$ \\
\hline 3. Kawasan permukiman & $\begin{array}{l}\text { Kawasan yang diperuntukkan sebagai pusat } \\
\text { pemerintahan. }\end{array}$ \\
\hline 4. Kawasan pemerintahan
\end{tabular}

Sumber: Direktorat Jenderal Penataan Ruang Kementerian Pekerjaan Umum, Pedoman Kriteria Teknis Kawasan Budidaya, 2007

Dari ulasan di atas tampak bahwa ada beberapa system dalam pengklasifikasian penggunaan lahan. System klasifikasi penggunaan lahan itu sendiri tidak ada yang sempurna dan universal. Hal ini dikarenakan sebuah system klasifikasi akan mengacu pada bentuk penggunaan lahan daerah tertentu, sehingga jika diterapkan untuk mengelompokkan atau membuat segmentasi mengenai kenampakan - kenampakan yang homogen (Puspitosari, 2007:20)

\section{DAFTAR PUSTAKA}

Arsyad, S. (2009). Konservasi tanah dan air. PT Penerbit IPB Press.

Indonesia, S. N. (2010). Klasifikasi penutup lahan. Jakarta. Indonesia.

Kaiser, E. J., Godschalk, D. R., \& Chapin, F. S. (1995). Urban land use planning (Vol. 4). Urbana: University of Illinois press.

Nurfatimah, N. (2020). Lahan, Air dan Pembangunan di Kec. Marioriwawo.

Sitawati, Anita. (2016) Materi Pokok Tata Guna dan Pengembangan Lahan. Tangerang Selatan: Universitas Terbuka. 